University of Windsor

Scholarship at UWindsor

$9-22-2017$

\title{
Short communication: Multi-scale topographic anisotropy patterns on a Barrier Island
}

\author{
Chris Houser \\ University of Windsor \\ Michael Bishop \\ Texas A\&M \\ Phil Wernette \\ Texas A\&M
}

Follow this and additional works at: https://scholar.uwindsor.ca/environmentalsciencepub

Part of the Earth Sciences Commons, and the Environmental Sciences Commons

\section{Recommended Citation}

Houser, Chris; Bishop, Michael; and Wernette, Phil. (2017). Short communication: Multi-scale topographic anisotropy patterns on a Barrier Island. Geomorphology, 297, 153-158.

https://scholar.uwindsor.ca/environmentalsciencepub/103

This Article is brought to you for free and open access by the Earth \& Environmental Sciences at Scholarship at UWindsor. It has been accepted for inclusion in Earth \& Environmental Sciences Publications by an authorized administrator of Scholarship at UWindsor. For more information, please contact scholarship@uwindsor.ca. 


\section{Accepted Manuscript}

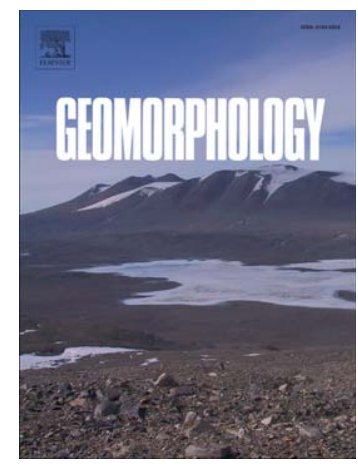

Short communication: Multi-scale topographic anisotropy patterns on a Barrier Island

Chris Houser, Michael Bishop, Phil Wernette

PII: $\quad$ S0169-555X(17)30404-X

DOI: doi: $10.1016 /$ j.geomorph.2017.09.026

Reference: $\quad$ GEOMOR 6171

To appear in: $\quad$ Geomorphology

Received date: 5 June 2017

Revised date: $\quad 20$ September 2017

Accepted date: $\quad 20$ September 2017

Please cite this article as: Houser, Chris, Bishop, Michael, Wernette, Phil, Short communication: Multi-scale topographic anisotropy patterns on a Barrier Island, Geomorphology (2017), doi:10.1016/j.geomorph.2017.09.026

This is a PDF file of an unedited manuscript that has been accepted for publication. As a service to our customers we are providing this early version of the manuscript. The manuscript will undergo copyediting, typesetting, and review of the resulting proof before it is published in its final form. Please note that during the production process errors may be discovered which could affect the content, and all legal disclaimers that apply to the journal pertain. 
Short Communication: Multi-Scale Topographic Anisotropy Patterns on a Barrier Island

Chris Houser $^{1}$, Michael Bishop ${ }^{2}$ and Phil Wernette ${ }^{2}$

${ }^{1}$ Department of Earth and Environmental Sciences

University of Windsor

Windsor, Ontario

Canada

${ }^{2}$ Department of Geography

${ }^{2}$ Center for Geospatial Science, Applications and Technology

Texas A\&M University

College Station, Texas

77843-3147

Corresponding Author: Chris Houser (chouser@uwindsor.ca) 


\begin{abstract}
Barrier islands exhibit a range of landforms that reflect the complex and varied combination of coastal and aeolian processes realized over the evolution of the island. A detailed analysis of the topography can be used to describe the evolution of a barrier island and provide insight on how it may be affected by a change in sea level, storm activity and wind exposure patterns. Topographic anisotropy, or the directional dependence of relief of landforms, can be used to determine the relative importance of different processes to island evolution at a range of scales. This short communication describes the use of scale-dependent topographic anisotropy to characterize the structure of Santa Rosa Island in northwest Florida. Scale-dependent topographic relief and asymmetry were assessed from a LiDAR-derived DEM from May 2004, a few months before the island experienced widespread erosion and overwash during Hurricane Ivan. This application demonstrates how anisotropy can be used to identify unique scaledependent structures that can be used to interpret the evolution of this barrier island. Results of this preliminary study further highlight the potential of using topographic anisotropy to controls on barrier island response and recovery to storms as well as island resiliency with sea level rise and storm activity.
\end{abstract}

Keywords: Barrier island, geomorphometry, topographic anisotropy, scale-dependent processes 


\section{Introduction}

Transgressive barrier islands are complex landforms that developed through a combination of coastal and aeolian processes, as they migrated to their current position from further offshore on the continental shelf. Barrier island transgression through landward migration or shoreline retreat is accomplished during storms capable of overtopping or breaching the dunes washing sediment to the backbarrier shoreline in the form of washover fans and terraces (Houser et al., 2008). For an island to transgress and remain a subaerial landform requires that the island can move landward and remain above sea level, which is in turn dependent on the ability of the dunes to recover following storms and moderate washover and inundation (Houser et al., 2017). Islands tend to be high in elevation (i.e., large continuous dunes) when the biophysical processes driving dune recovery dominate, but when storm erosion is frequent and extensive, islands can enter a low-elevation state (characterized by small discontinuous dunes) that makes the island susceptible to erosion and washover during relatively mild storm conditions (Duran and Moore, 2013; Houser et al., 2015). Because the overwash threshold is reduced in lower elevation areas, gaps between larger dunes tend to be reinforced with each storm (Houser and Hamilton, 2009; Houser, 2012; Weymer et al., 2015) leading to a biogeomorphic feedback that further reinforces the variation in the dune line (Stallins and Parker, 2003; Duran and Moore, 2013). The sediment transferred to the backbarrier through washover plays an important role in determining the morphology of the backbarrier shoreline, and in maintaining island width. It is also possible to have a regular variation in washover and dune heights alongshore in response to edge wave set up or even infragravity resonance (Orford and Carter, 1984) that can be reinforced by subsequent washover or blowout development (Jewell et al., 2014; 2017). 
The net result of the combined and in some cases inter-dependent coastal, aeolian, and ecological processes on a barrier islands is a complex mosaic of topographic variation and features across a range of scales. On many barrier islands, small-scale variations in morphology associated with shoreface $(>1000 \mathrm{~m})$ and surf/swash processes $(<1000 \mathrm{~m})$ are superimposed on a larger-scale variability associated with the framework geology that influences beach and dune morphology through variations in wave energy or sediment supply and texture (McNinch, 2004; Browder and McNinch, 2006; Houser and Matthew, 2011; Houser, 2012; Warner et al, 2014; Wernette et al., in review). It is therefore, possible to interpret the evolution of a barrier island based purely on an analysis of scale-dependent topographic variation and relief features, but the superposition of local-scale relief on mesoscale relief produces subtle relief features that are not readily visible upon examination of a digital elevation model using standard visualization or statistical techniques. Visualization of subtle and overlapping features has traditionally been accomplished through spectral or wavelet techniques (e.g. Houser et al., 2008) or higher-order exploratory statistics including principal component analysis (PCA; Barrineau et al., 2016).

As recently demonstrated by Roy et al. (2015), the anisotropy, or directional dependence, of topographic features can be used to assess the magnitude and orientation of past and present processes across multiple length scales. Specifically, they used topographic anisotropy of valleys and ridges in a mountainous environment to determine the magnitude and orientation of past and present tectonic strain fields. Surf, swash and aeolian landforms generate anisotropic features (bars, beaches and dunes) that are or near perpendicular to the primary transport direction, while extensive overwash (or barrier breakdown; Orford et al., 1991) can result in an isotropic topography in the form of washover fans and terraces. However, where there is sluicing discrete overwash it is possible to develop anisotropic features that are perpendicular to 
the barrier and distinct from the anisotropy of the beach and dune (Orford et al., 1991) This suggests that topographic anisotropy can be used to link barrier island morphology to formative process(es) on Santa Rosa Island in northwest Florida, but the technique has not been demonstrated in a coastal environment. The purpose of this short communication is to determine whether topographic anisotropy can be used to identify scale-dependent features in coastal LiDAR data.

\section{Study Site}

This demonstration of topographic anisotropy in a coastal environment was completed on a section of Santa Rosa Island in northwest Florida (Fig. 1). Santa Rosa Island is a narrow sandy Holocene barrier island extending $96 \mathrm{~km}$ from East Pass near Destin to Pensacola Pass in the west. The focus of this study is a $2.5 \mathrm{~km}$ stretch of the island that was impacted by hurricanes Ivan (2004), Dennis (2005) and Katrina (2005). This area has also been the focus of numerous previous studies of storm response and recovery within the Gulf Islands National Seashore (e.g., Houser et al., 2008; 2015; Houser and Hamilton, 2009; Claudino-Sales et al., 2010). The island is fronted by a ridge and swale bathymetry that creates a coincident variation in beach and dune morphology ranging from transverse bar and rip morphology and small discontinuous dunes landward of the swales to longshore-bar and trough with relatively large dunes landward of the offshore ridges that serve as an offshore source of sediment (see Short and Hesp, 1982; Hesp, 2002; Houser, 2009). A geological survey by Houser (2012) supported an earlier theory that the ridge and swale topography may be a transgressive surface, representing a multi-scale feedback of the response and recovery of the island to storms. In this respect, the variation in beach and dune morphology exhibits a strong dependency on the framework geology (see Houser et al., 
2008; 2011) in addition to the small-scale variations associated with coastal and aeolian processes during storm and post-storm recovery.

\section{Methodology}

\section{LiDAR and Bathymetry Data}

Topographic anisotropy was examined using light detection and ranging (LiDAR) data collected by the US Geological Survey Center for Coastal and Watershed Studies before Hurricane Ivan (May 2004), a few months before the island experienced widespread erosion and overwash. The data are a product of the USACE and Optech Inc., which is more commonly known as the Compact Hydrographic Airborne Rapid Total Survey (CHARTS). This system is a combination of a $1000 \mathrm{~Hz}$ hydrographic sensor, a $10000 \mathrm{~Hz}$ topographic sensor, and an image sensor. The point spacing for the pre-Ivan data was $\sim 0.3 \mathrm{~m}$. All data were first converted from raw xyz data into ArcSDE feature classes. The raw point data were interpolated using inverse-distance weighting (IDW) with the IDW power parameter set to four to decrease the influence of distant points, and the search radius was limited to the closest eight points. The RMSE was $0.34 \mathrm{~m}$.

\section{Topographic Anisotropy}

Scale-dependent topographic relief and asymmetry were assessed from the LiDAR-derived DEM from May 2004. LiDAR and bathymetric data from Santa Rosa Island in Northwest Florida are used to examine the directional dependence of the barrier system at a range of spatial scales and azimuth intervals $\left(5^{\circ}\right)$ around each pixel. For each azimuth direction, we used the standard deviation $(\sigma)$ of elevation values out to fixed transect distances to represent a low frequency proxy of topographic relief. In this way, our scale-dependent analysis accounts for variations in distance and direction. We then search over all azimuth directions to find the maximum and 
minimum relief to characterize topographic anisotropy. The degree of anisotropy (a) is computed as the ratio of the maximum standard deviation $\left(\sigma_{\max }\right)$ to the minimum standard deviation $\left(\sigma_{\min }\right)$ from all azimuth angles at a given transect distance, such that:

$$
a=\frac{\sigma_{\max }}{\sigma_{\min }} .
$$

The azimuth angles of the maximum and minimum relief for each pixel were also transformed to generate images that depict the orientation structure of the barrier island landscape (see Fig. 2). This was accomplished by transforming these azimuth angles using the cosine functions for easier presentation of the orientations. This also permits classification of orientation structures on the landscape, using pattern recognition approaches. The resulting geomorphometric parameters (images) can then be visualized to examine the topographic anisotropy characteristics of the landscape. Topographic anisotropy patterns exhibit a unique orientation structural fabric that highlights multi-scale topographic variation caused by surface processes and events. The resulting landscape fabrics allow for new interpretations of coastal environments that are not possible in the field, and may not be possible with other spatial analysis approaches to landscape interpretation.

\section{Discussion of Results}

This demonstration of scale-dependent topographic analysis was completed at discrete distances of $125,250,500,750$ and $1000 \mathrm{~m}$, closely corresponding to peak spectral and wavelet frequencies in the alongshore variation in washover and 2004 dune height (see Houser et al., 2008; Houser and Hamilton, 2009; Houser, 2012). The degree of anisotropy and the cosine of the azimuthal orientation of minimum relief is presented in Fig. 3 for all distances. At the 1000 $\mathrm{m}$ scale (Fig. 3a), the island exhibits a strong degree of anisotropy along the seaward half of the island where the morphology is dominated by beach and dune features (see Fig. 4). Strong 
anisotropy is, however, limited in the cross-shore at the cuspate headlands (widest sections of the island), but extends towards the backbarrier shorelines in the narrow sections of the island between headlands where washover was observed during Hurricanes Opal, Erin and Ivan (see Houser et al., 2008). The orientation of the minimum relief exhibits a complex pattern that is centered on the cuspate headlands (Fig. 3f), with minimum relief (the major axis of the ellipse; see Fig. 2) oriented alongshore in the area dominated by the beach, backshore and dune morphology. In the narrow sections of the island, the minimum relief structure exhibits a crossshore pattern in the narrow sections of the island that are dominated by washover during storms. Along the backbarrier shoreline on both the east and west side of the cuspate headland, the relief structures associated revealed by the anisotropic orientation is consistent with a bi-directional alongshore transport and beach ridge development from the washover sediment deposited along the backbarrier shoreline. This pattern is not visible in the original LiDAR data (see Fig. 1), and is consistent with the evolution of the cuspate headlands described at this site by Houser (2012).

The bi-directional beach features on the landward side of the cuspate foreland are also visible at the 750-m length scale (Fig. 3g), although these features extend across more than half of the island. The orientation and extent of these minimum relief structures suggest that the cuspate headland has largely accreted landward, perpendicular to the island and has not migrated alongshore. Along the margins of the cuspate headland, the orientation of the minimum relief is consistent with the alongshore variation in the overwash terraces observed at the 1000-m length scale. This would suggest that the alongshore variation in washover, which is dependent on the alongshore variation in foredune height, is a persistent feature of this island across scales. The washover dominated features are also visible at $500 \mathrm{~m}$ (Fig. 3h), and begins to dominate over the alongshore-oriented anisotropy associated with the foredune along the seaward side of the island. 
However, the minimum relief structure no longer visible at the 250-m length scale (Fig. 3i), and is replaced by multiple orientations. Anisotropy is only visible along the seaward and backbarrier shorelines, and the paved road through the center of the island. This pattern and the strong anisotropy of the road is also visible at the 125-m length scale (Fig. 3j).

The parabolic dunes present at the cuspate headlands (see Houser et al., 2008) exhibit strong multi-directional minimum relief patterns at the $250-\mathrm{m}$ length scale (Fig. 3i). They are visible as the broad circles with a high degree of anisotropy at each cuspate headland. This is characteristic of parabolic blowouts, in which the dune ridge, trailing arms and deflation basin that each have different orientations (Hesp, 2002; Jewell et al., 2014; 2017;). The strong degree of anisotropy associated with the parabolic blowouts is also visible at $100 \mathrm{~m}$, but the lack of these features at scales $>500 \mathrm{~m}$ suggests that they are relatively small localized features. Smaller multi-directional relief patterns are visible across the 125-m scale, and associated with small localized coppice dunes in the narrow sections of the island or remnant backbarrier dunes laterally eroded by storm overwash (Fig. 3j). At these smaller scales the anisotropic orientation highlights the small-scale cusp and horn beach morphology associated with the pre-dominant transverse bar and rip morphology on the beach (Barrett and Houser, 2012). These small-scale surf and swash zone processes are superimposed on the larger scale morphological structuring resulting from the ridge and swale framework geology of the inner-shelf that is visible at the larger scales.

\section{Conclusions}

The complex topography of Santa Rosa Island visible in the LiDAR DEM and the subtlety of barrier island topography can make it difficult to interpret scale-dependent process-form relationships. At scales previously identified as being associated with the framework geology 
(Houser et al., 2008; Houser and Hamilton, 2009; Houser, 2012), the topographic anisotropy reveals cross-shore directed washover features in the narrow sections of the island and strong alongshore-directed dune morphology at the cuspate headlands. The bi-directional nature of the minimum relief structural patterns along the backbarrier shoreline is evidence of the cuspate headland accreting landward in response to the alongshore transport and deposition of sediment deposited by washover through the narrow sections of the island. At scales associated with alongshore variations in the shoreface, the minimum relief structure reveals the alongshore variation in washover that extends to the backbarrier shoreline in the narrow sections of the island and is limited in landward extent at the cuspate headlands. Superimposed on this morphology are landforms consistent with small-scale aeolian, surf and swash zone processes. The ability to identify features associated with scale-dependent processes and/or controls provides an opportunity to interpret LiDAR data, develop morphometric maps and guide fieldbased sedimentological and geophysical investigations that typically depend on purpose sampling. This approach also provides an opportunity to examine how barrier islands respond to repeated storm events and sea level rise, with changes in topographic anisotropy representing an early warning of a loss of island resiliency. 


\section{References}

Barrett, G., Houser, C., 2012. Identifying hot spots of rip current activity using wavelet analysis at Pensacola Beach, Florida. Physical Geography 33, 32-49.

Barrineau, P., Dobroveya, I., Bishop, M., Houser, C., 2016. Deconstructing polygenetic landscapes through a multi-scale analysis of a digital elevation model for the South Texas Sand Sheet. Geomorphology 258, 51-57.

Browder AG, McNinch, J.E., 2006 Linking framework geology and nearshore morphology: correlation of paleo-channels with shore-oblique sandbars and gravel outcrops. Marine Geology 231, 141-162.

Claudino-Sales V, Wang P, Horwitz M.H., 2010. Effect of Hurricane Ivan on coastal dunes of Santa Rosa Barrier Island, Florida: characterized on the basis of pre-and poststorm LIDAR surveys. Journal of Coastal Research, 470-484.

Durán O., Moore, LJ., 2013. Vegetation controls on the maximum size of coastal dunes. Proceedings of the National Academy of Sciences 110(43), 17217-17222.

Hesp, P., 2002. Foredunes and blowouts: initiation, geomorphology and dynamics. Geomorphology 48(1), 245-268.

Houser, C., Hapke, C., Hamilton, S., 2008. Controls on Coastal Dune Morphology, Shoreline Erosion and Barrier Island Response to Extreme Storms. Geomorphology 100, 223-240.

Houser, C., Barrett, G., Labude, D., 2011. Alongshore variation in the rip current hazard at Pensacola Beach, Florida. Natural Hazards 57, 501-523.

Houser, C., 2009. Synchronization of transport and supply in beach-dune interaction. Progress in Physical Geography 33(6), 733-746.

Houser, C., Hamilton, S., 2009. Sensitivity of post-hurricane beach and dune recovery to event frequency. Earth Surface Processes and Landforms 34, 613-628.

Houser, C., and Mathew, S., 2011. Variability in foredune height depends on the alongshore correspondence of transport potential and sediment supply. Geomorphology 125, 62-72.

Houser, C., 2012. Feedback between ridge and swale bathymetry and barrier island storm response and transgression. Geomorphology 173/174, 1-16.

Houser, C., Wernette, P., Rentschler, T., Jones, H., Hammond, B., Trimble, S., 2015. Post-storm beach and dune recovery: implications for barrier island resilience. Geomorphology 234, 54-63. 
Houser et al., 2017 Houser, C., Barrineau, P., Hammond, B., Saari, B., Rentschler, E., Trimble, S., Wernette, P, Weymer, B., Young, S., 2017. Role of the foredune in controlling barrier island response to sea level rise. In: Barrier Islands, edited by Moore, L., and Murray, B.

Jewell M., Houser, C., Trimble, S., 2014. Initiation and evolution of blowouts within Padre Island National Seashore, Texas. Ocean \& coastal management 95, 156-164.

Jewell, M., Houser, C., Trimble, S., 2017. Phases of blowout initiation and stabilization on Padre Island revealed through ground-penetrating radar and remotely sensed imagery. Physical Geography, 1-22.

McNinch J.E., 2004. Geologic control in the nearshore: shore-oblique sandbars and shoreline erosional hotspots, Mid-Atlantic Bight, USA. Marine Geology 211:121-141.

Orford, J.D., Carter, R.W.G., 1984. Mechanisms to account for the longshore spacing of overwash throats on a coarse clastic barrier in southeast Ireland. Marine Geology 56(1-4), 207-226.

Orford, J.D., Carter, R.W.G., Forbes, D.L., 1991. Gravel barrier migration and sea level rise: some observations from Story Head, Nova Scotia, Canada. Journal of Coastal Research, 477-489.

Orford, J.D., Anthony, E.J., 2011. Extreme events and the morphodynamics of gravel-dominated coastal barriers: Strengthening uncertain ground. Marine Geology 290(1), 41-45.

Roy, S.G., Koons, P.O., Osti, B., Upton, P., Tucker, G.E., 2016. Multi-scale characterization of topographic anisotropy. Computers and Geosciences 90, 102-116.

Short, A.D., Hesp, P.A., 1982. Wave, beach and dune interactions in southeastern Australia. Marine geology 48(3-4), 259-284.

Stallins J.A., Parker A.J., 2003. The influence of complex systems interactions on barrier island dune vegetation pattern and process. Annals of the Association of American Geographers 93,13-29.

Warner, J.C., List, J.H., Schwab, W.C., Voulgaris, G., Armstrong, B. and Marshall, N., 2014. Inner-shelf circulation and sediment dynamics on a series of shoreface-connected ridges offshore of Fire Island, NY. Ocean Dynamics 64(12), 1767-1781.

Weymer B.A., Houser C., Giardino R., 2015. Post-storm evolution of beach-dune morphology: Padre Island National Seashore, Texas. Journal of Coastal Research 31, 634-644. 
Fig. 1. Map of Santa Rosa Island in northwest Florida, showing LiDAR DEM of the study area, and oblique aerial photographs of the site before Hurricane Ivan in 2004.

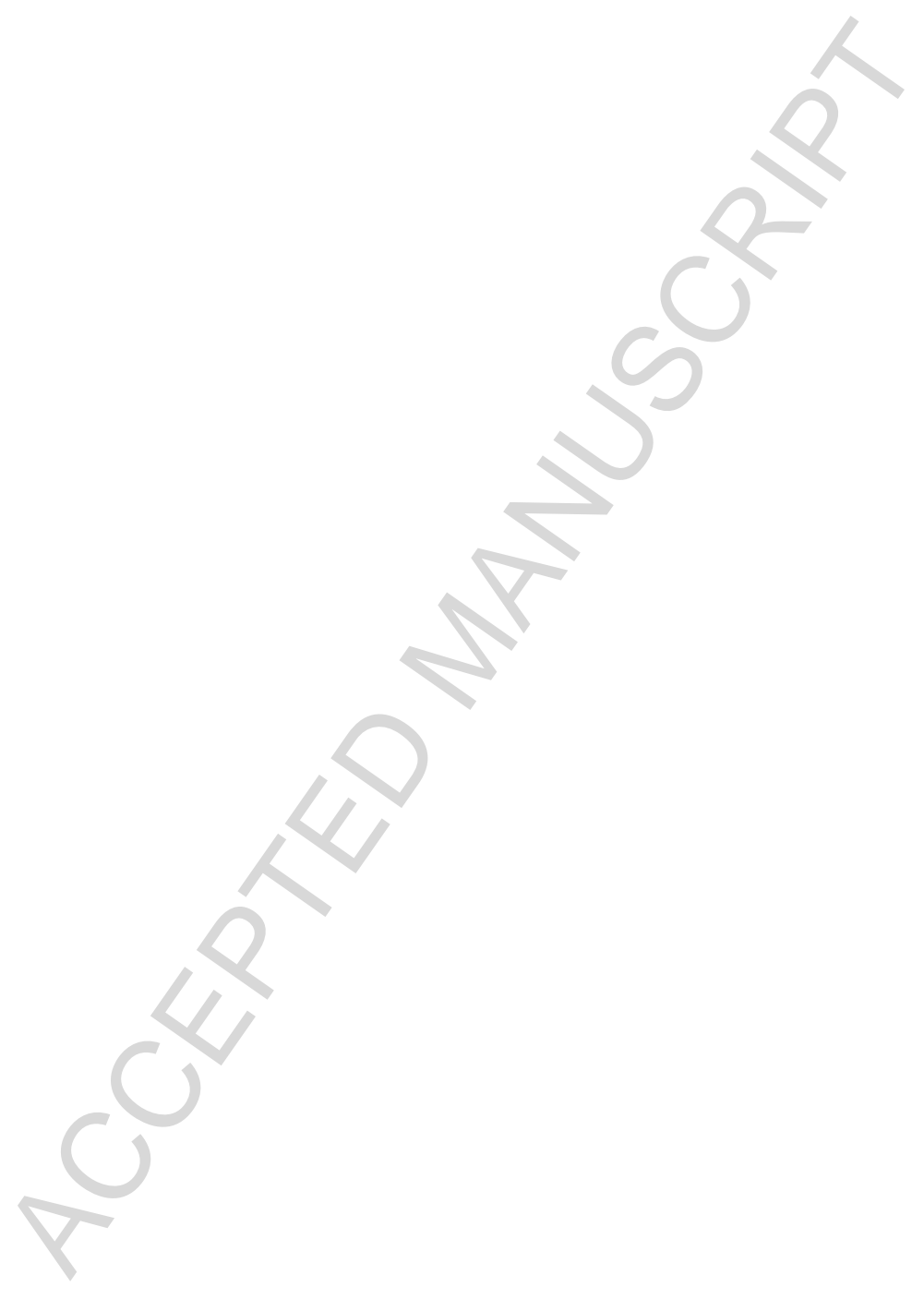


Fig. 2. Example of how topographic anisotropy is calculated from a LiDAR dataset. For clarity, the example only shows azimuthal directions in $15^{\circ}$ intervals $\left(5^{\circ}\right.$ was used in the full analysis $)$ for 3 length scales $\left(\mathrm{L}_{1}, \mathrm{~L}_{2}\right.$ and $\left.\mathrm{L}_{3}\right)$. Topographic variance is calculated along each azimuth for each length scale independently, and the degree of anisotropy $(a)$ is calculated from Equation 1 as the ratio of the maximum variance to the minimum variance. Anisotropy orientation is based on the direction of minimum variance and is presented in this example as an ellipse for each length scale. The more defined the ellipse, the stronger the anisotropy, and the more round the ellipse to more that the topography is isotropic at that scale. For example, Point 1 exhibits strong topographic anisotropy at the largest scale $\left(\mathrm{L}_{3}\right)$ and isotropy at the smallest scale $\left(\mathrm{L}_{1}\right)$. 
Fig. 3. Degree of anisotropy (a-e) and azimuthal orientation of minimum relief (f-j).

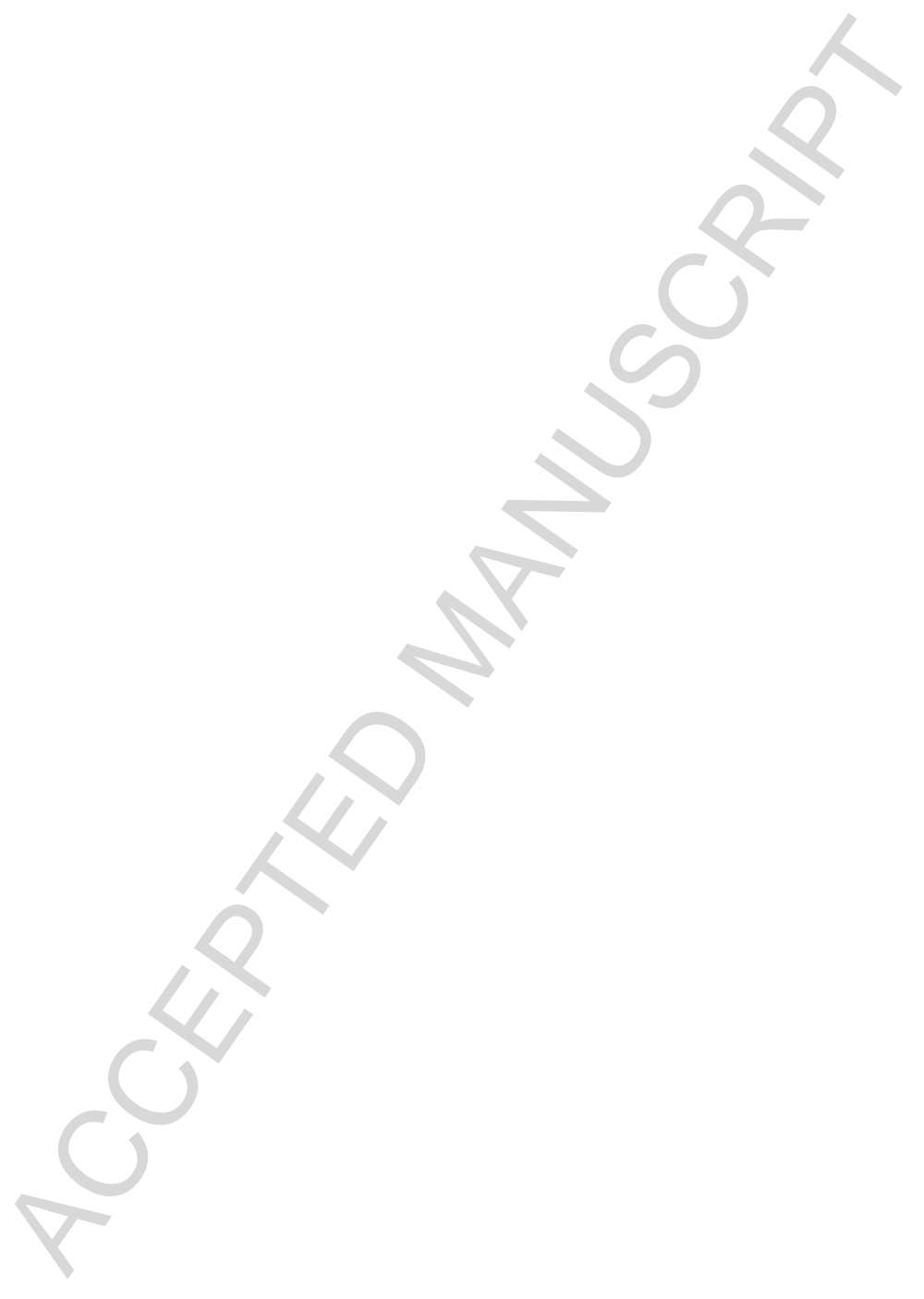


Fig. 4. LiDAR DEM overlain on a digital orthophoto showing key landforms referenced in text and based on the interpretations of Houser (2012). 


\section{Figure 1}

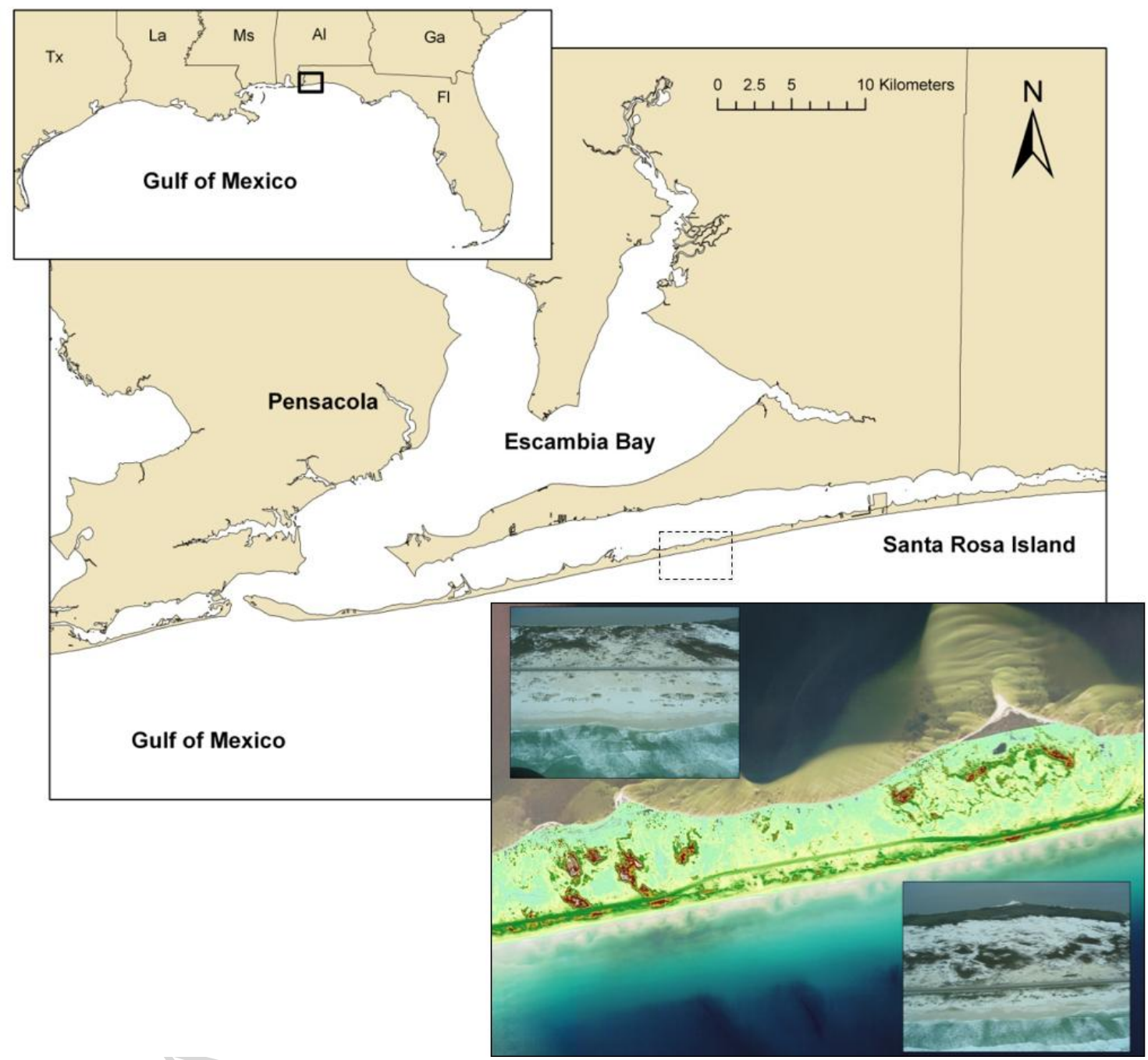


Figure 2
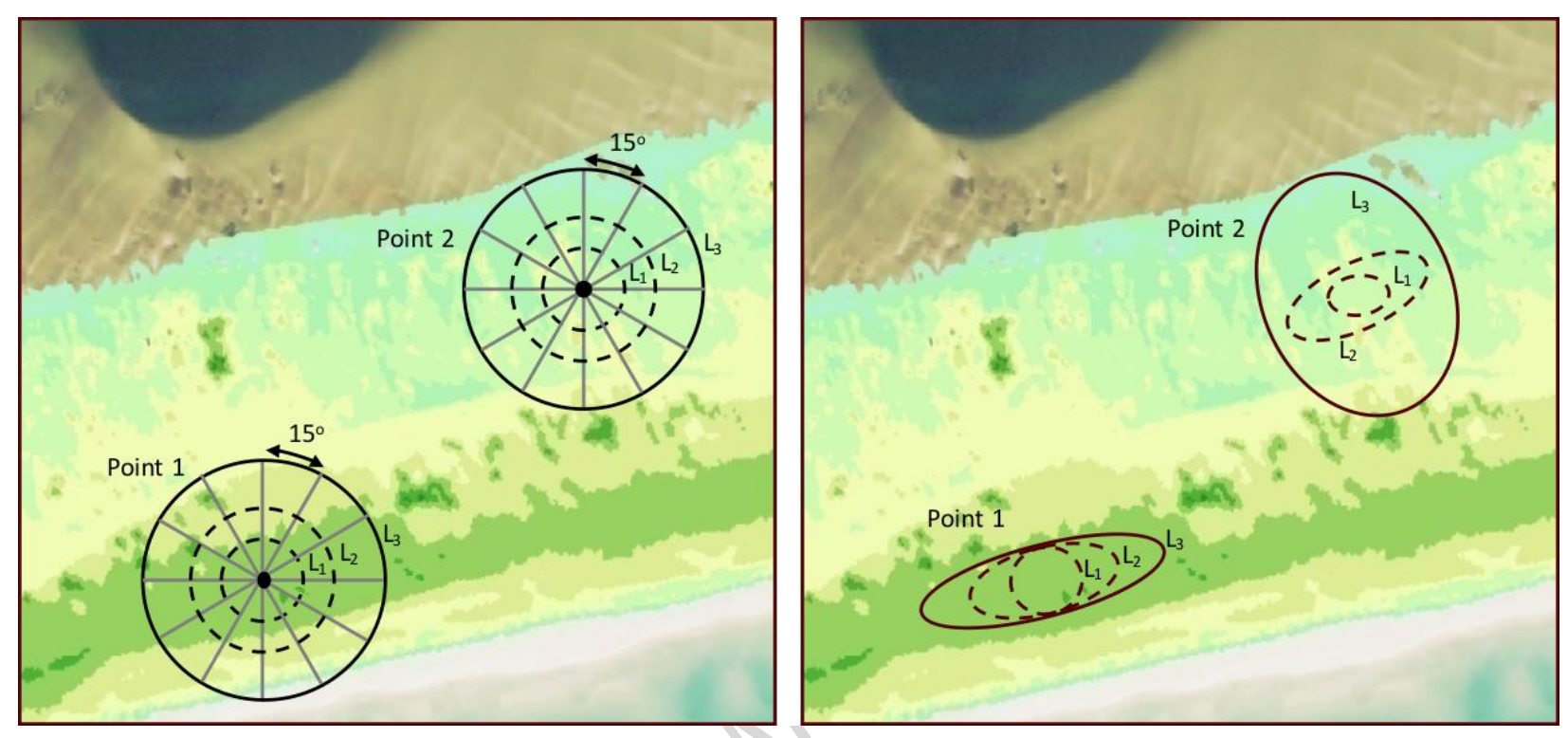


\section{ACCEPTED MANUSCRIPT}

\section{Figure 3}

a) $1000 \mathrm{~m}$
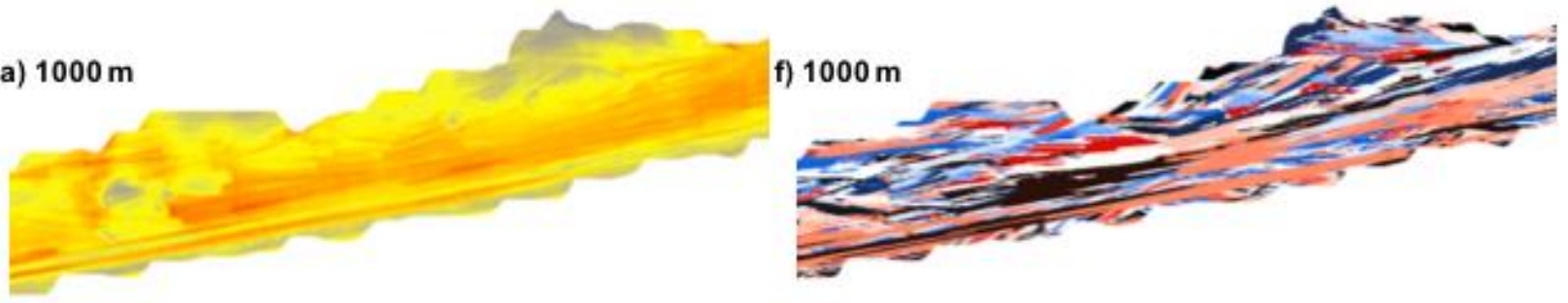

b) $750 \mathrm{~m}$

g) $750 \mathrm{~m}$
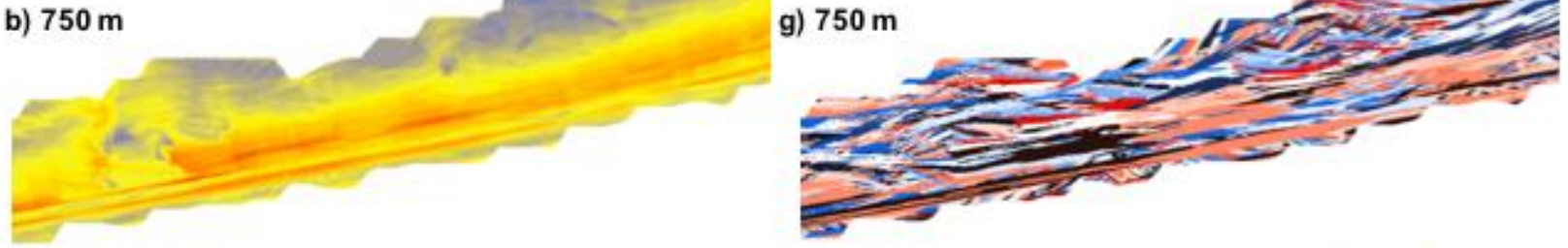

c) $500 \mathrm{~m}$

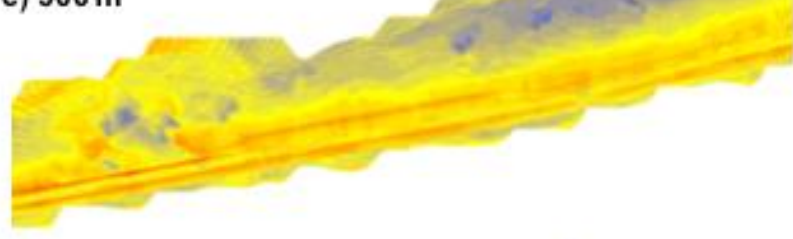

h) $500 \mathrm{~m}$

d) $250 \mathrm{~m}$
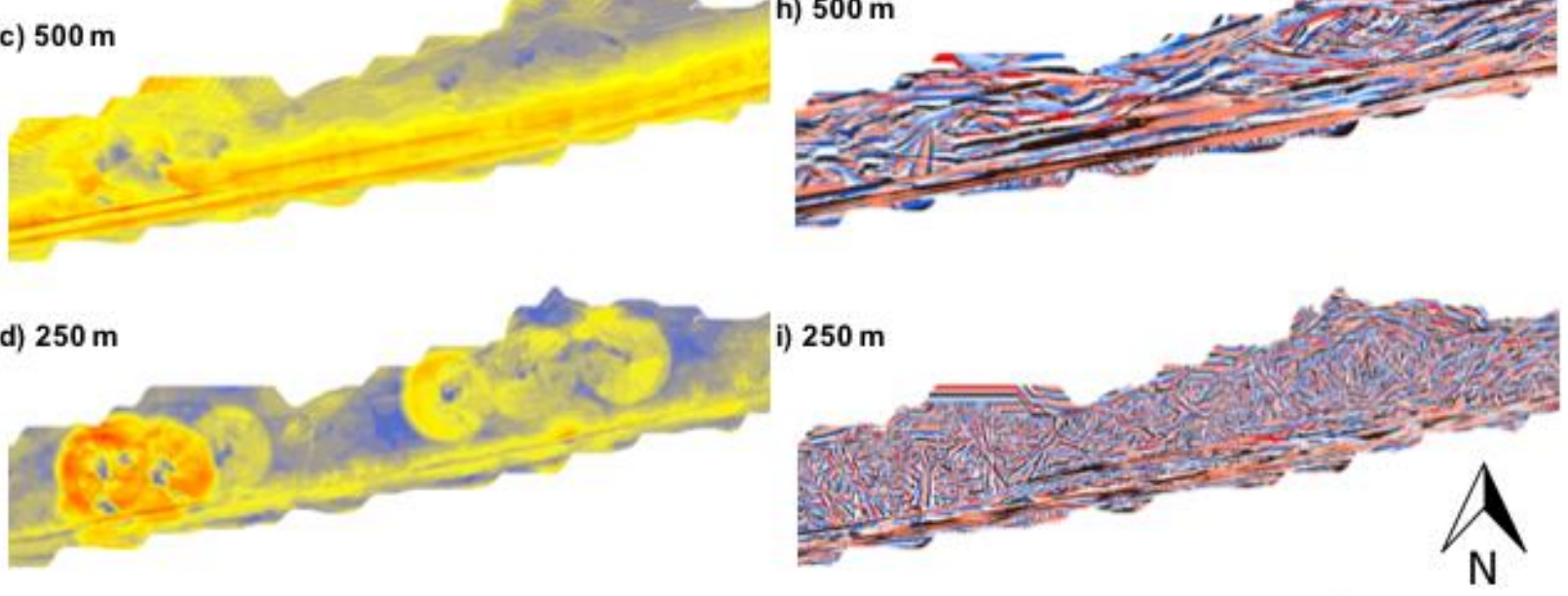

e) $125 \mathrm{~m}$

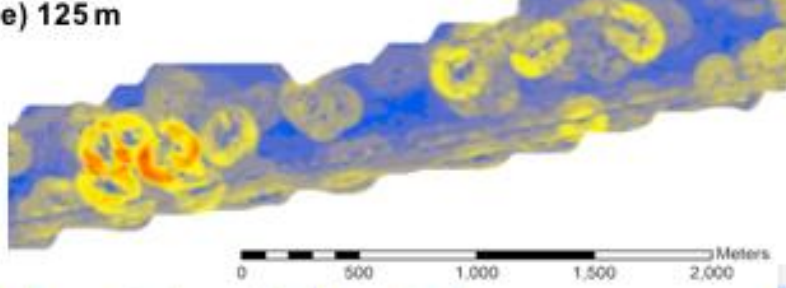

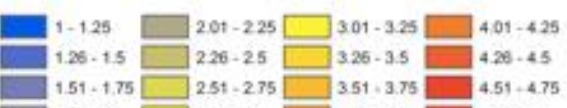

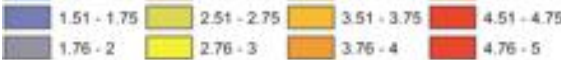

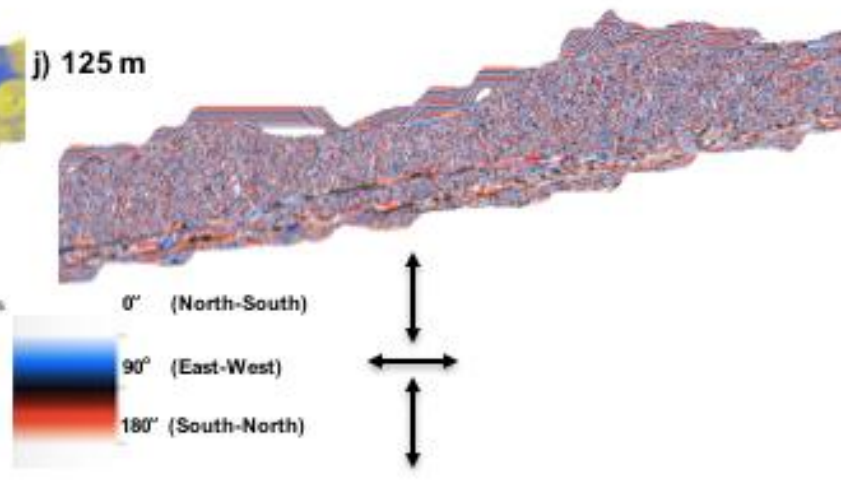


Figure 4

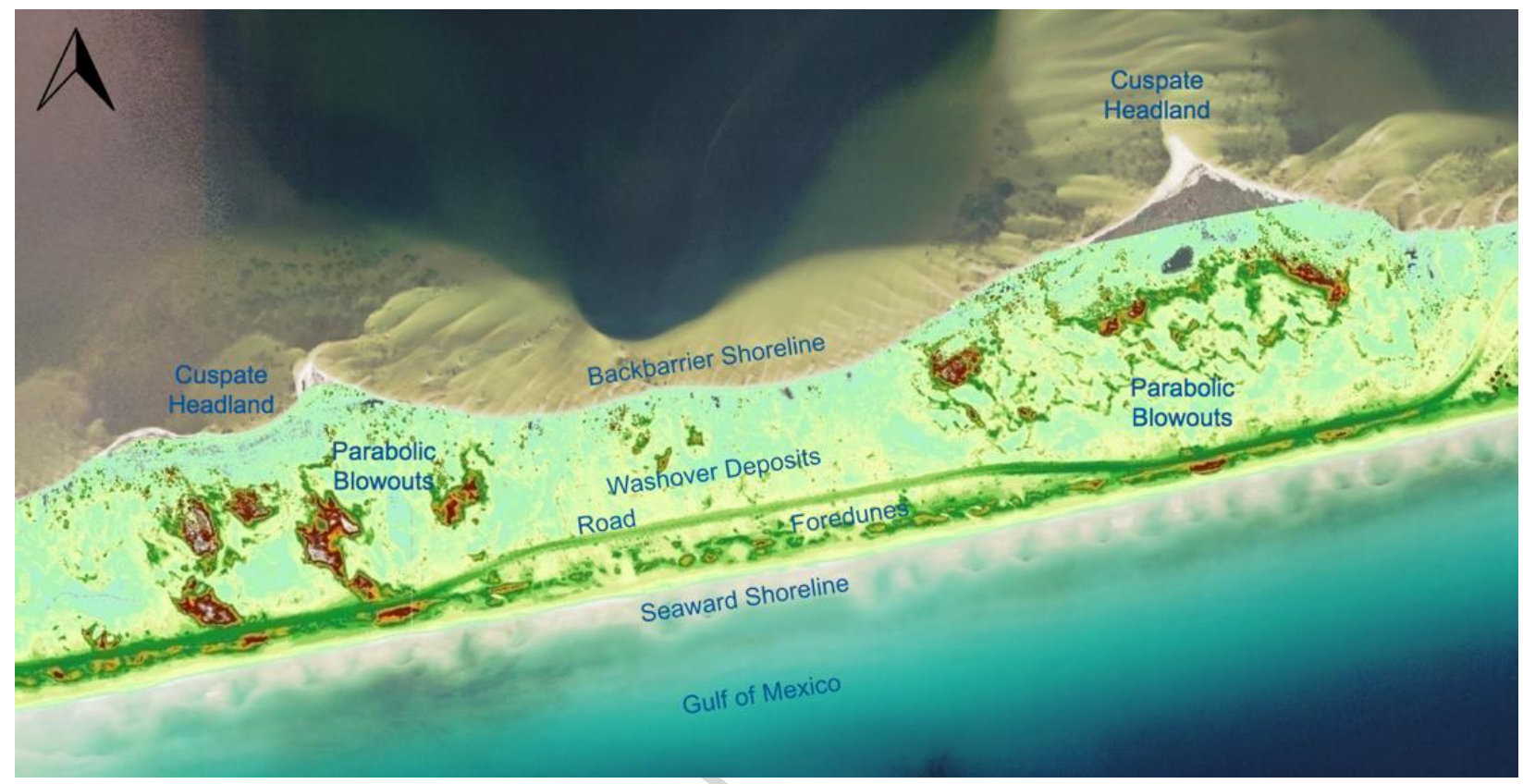




\section{Highlights}

- Topographic anisotropy can identify unique scale-dependent structures

- Scale-dependent structures can be used to infer processes at those scales

- Anisotropy can be used to describe barrier island evolution 